\title{
Microcredit Impact on Socio-Economic Development and Women Empowerment in Low-Income Countries: Evidence from Yemen
}

\author{
Samer Ali Al-shami ${ }^{1, *}$, Abdullah Al Mamun ${ }^{2}\left(\mathbb{D}\right.$, Nurulizwa Rashid $^{3}$ and Mohammed Al-shami ${ }^{4}$ \\ 1 Institute of Technology Management and Entrepreneurship, Universiti Teknikal Malaysia Melaka, \\ Melaka 76100, Malaysia \\ 2 Faculty of Business and Management, UCSI University, Kuala Lumpur 56000, Malaysia; \\ abdullaham@ucsiuniversity.edu.my \\ 3 Faculty of Technology Management and Technopreneurship, Universiti Teknikal Malaysia Melaka, \\ Melaka 76100, Malaysia; nurulizwa@utem.edu.my \\ 4 Faculty of Education, Sana'a University, Sanaa 1247, Yemen; mohammedalshami075@gmail.com \\ * Correspondence: samerali@utem.edu.my or samshami79@gmail.com
}

Citation: Al-shami, S.A.; Al Mamun, A.; Rashid, N.; Al-shami, M. Microcredit Impact on Socio-Economic Development and Women Empowerment in Low-Income Countries: Evidence from Yemen. Sustainability 2021, 13, 9326. https://doi.org/10.3390/ su13169326

Academic Editor: Chia-Lin Chang

Received: 5 July 2021

Accepted: 16 August 2021

Published: 19 August 2021

Publisher's Note: MDPI stays neutral with regard to jurisdictional claims in published maps and institutional affiliations.

Copyright: (C) 2021 by the authors. Licensee MDPI, Basel, Switzerland. This article is an open access article distributed under the terms and conditions of the Creative Commons Attribution (CC BY) license (https:// creativecommons.org/licenses/by/ $4.0 /)$.

\begin{abstract}
Microcredit financing is extensively considered as an effective development method for poverty mitigation and women empowerment. Nevertheless, relevant studies reflected opposing outcomes on microfinance effects consisting of positive, zero, and negative impacts. Thus, this research investigated Al-Amal Bank's microcredit impacts on women empowerment in Yemen, one of the poorest Middle Eastern nations. A panel dataset and primary and secondary data were gathered through household surveys and propensity score matching to restrict intangible variables' possible effects. The empirical results revealed that microcredit had a significant positive effect on monthly household incomes and accumulated asset values. Although microcredit facilitated female entrepreneurship and income generation for improved household incomes and expenditure, no influence was found on female household decisions and mobility following the patriarchal system practised in many Arabian nations, including Yemen. Hence, the study finding has theoretically and practically contributed to the body of knowledge in three ways. First, a novel proof of how microcredit interactions affected several Yemeni women empowerment elements was identified. This study also provides new insight into the empowerment theory by explaining how access to microcredit influences numerous features of women's economic and social empowerment. Lastly, social and family traditions significantly influenced female attributes and lifestyles by reflecting how communal and family rituals affected microcredit impacts on women empowerment and vice versa. Conversely, this study guides Yemeni policymakers and those from other nations on extending financial services for self-development to reduce poverty and drive women empowerment rather than relying on government and international agencies.
\end{abstract}

Keywords: microcredit; socio-economic development; women empowerment; Yemen

\section{Introduction}

Poverty eradication has globally garnered humanitarian organisations' attention on development, prosperity, and public security-oriented roles. Consequently, governments and supporting organisations have collaborated to mitigate poverty. Poverty remains rife as a perpetually limiting social dilemma that requires suitable innovations complementing social nature and attributes despite the attempts taken. Microcredit drew substantial attention from the United Nations (UN) among the poverty reduction models and policies as one of the most efficient poverty eradication methods [1]. Microcredit facilitated poverty mitigation, particularly in underprivileged communities, such as in rural Bangladesh, Africa, Southeast Asia, and Middle Eastern nations. Notwithstanding the economic renown of microcredit development since 1976 [2], underprivileged financing classes denoted credit 
risk for three reasons: (a) the borrower's inability to deliver credit guarantees, (b) the knowledge gap between banks and borrowers that induced credit risk [3], (c) the relatively small loan size requiring supervision to ensure that the loan was utilised for the intended purpose and secure refunds [4].

With the fairly high loan costs and risk factors, the Kremen Bank offered a robust model to minimise study gap implications by selecting women as beneficiaries under social borrowing. The strategy proved highly successful with household financial developments as female behaviour consumption primarily involved household quality improvements, such as income [5], food [6], children's education, and health [7]. Collective lending between five to ten women under social collateral efficiently minimised the knowledge gap between banks and borrowers. As women were ideally trustworthy, the attribute strengthened bank-women rapport. Collective lending between five to ten women under social collateral was an efficient method to minimise the knowledge gap between banks and borrowers. Subsequently, supervisory costs are reduced as supervision would transform into collective accountability [8]. Hence, banks could restructure (increase) loan amounts to benefit borrowers and banks.

Microcredit proponents opined that female inclusion (women from orthodox communities dominated by a patriarchal system in financial services) improved social standing and determined women's social structures and family rules. The underlying microcredit logic implied that women with capital could develop small income-generating businesses that alleviated poverty by supplementing household expenses [9] and enhanced self-confidence and efficacy through household decision-making [10]. Arguably, microcredit did not facilitate women empowerment and poverty mitigation as microcredit impacts varied across nations based on financial and social factor variances and microcredit financing practices [11]. For example, studies undertaken in Thailand [12] and Vietnam [12] asserted the absence of microcredit effects. Additionally, research in Sub-Saharan Africa [5] indicated mixed microcredit impacts (positive, zero, and negative), specifically on loan utilisation decisions where husbands named the spouses as proxies for loans and loans repayment. Other studies affirmed the negative impacts of microcredit in the Philippines and Ghana $[3,13]$. Literary contradictions posed questions on microcredit efficiency in poverty mitigation and women empowerment. Debatably, microcredit impacts were determined by borrowers' socio-economic aspects. For example, microcredit positively influenced wealthy borrowers but negatively impacted inferior counterparts from India and the Philippines [11]. The microcredit impact on women empowerment was affected by various social norms and family rules, such as loans and business decisions. Although microcredit catalysed positive financial impacts, the influence could be linked to negative impacts, such as marital friction, increased child labour, and the perceived negligence of female domestic duties [13]. Several studies recently examined the role of microcredit in less developed countries, particularly in the Middle East, such as in Ethiopia [14], Djibouti [15], and Sudan [5]. These studies focused on the economic impact, particularly on household income compared to social empowerment, and found that microfinance impact varies from positive in Sudan to no impact in Ethiopia and Djibouti. Although many studies were undertaken in Central and South Asian, Sub-Sahara African, and South American nations, only a few counterparts examined microcredit roles in Middle Eastern nations, specifically Yemen. The scarcity indicated a study gap on microcredit utilisation in poverty mitigation and women empowerment in conventional and undeveloped nations. Thus, this study aimed to investigate microcredit impacts on women regarding household finances and social decision empowerment. Thus, this study aimed to investigate microcredit impacts on women regarding household finances and social decision empowerment. The study finding provided three primary contributions:

a. The literature suggests that microcredit's impact on women empowerment differs from one country to another, caused by the distinct demographic, social factors, and microcredit institutions. Therefore, a novel proof of how microcredit interactions affected several Yemeni women empowerment elements was identified. 
b. This study incorporates both economic and social effects, as most past studies emphasised the economic effect of microcredit. Thus, the study brings new insight to empowerment theory by providing a clear understanding of how access to microcredit influences women empowerment.

c. Social and family traditions significantly influenced female attributes and lifestyles, reflecting how communal and family rituals affected microcredit impacts on women empowerment and vice versa.

\section{Literature Review}

\subsection{The Yemeni Socio-Economy}

Yemen is an Arabian nation with approximately 29 million citizens, with the majority living below the poverty line. The southern parts of Yemen were previously colonised by the British, whereas the northern counterparts were subjected to the rule of the Mutawakkilite Kingdom of Yemen. A revolution occurred in the north in 1962, toppling the monarchy and forming a republican. Conversely, a subsequent revolt against the British colony in the south ended the feud in 1967. Yemen was initially split in two, with the Yemen Arab Republic in the north and the People's Democratic Republic of Yemen in the south. The northern region incorporated a capitalist financial system [12], whereas the southern counterpart implemented a socialist version [16].

North and South Yemen were eventually unified in 1990 under a federal state called the Republic of Yemen, with the capital, Sana'a, in the north. Yemen was afflicted with several civil wars (involving northern and southern parties) between 1962 and 1990 that impacted national stability and financial development. The three civil war causes were depicted in the study context: (a) internal factors, i.e., contradictory loyalties, tribal system influences against the civil counterpart, and high illiteracy levels; (b) regional interventions between 1962 and 1967 (specifically in Egypt) that facilitated the 1962 revolution against the northern Yemeni monarchy and Saudi Arabian support; and (c) the civil war of secession of 1994.

Saudi Arabia increasingly intervened in Yemeni affairs by manipulating the deteriorating financial landscape. The interference was reflected through tribal allegiance exploitations for counterforce development that threatened the central government and instigated bloody civil wars that killed thousands of Yemenis and deterred national economic development efforts. Nonetheless, Yemen experienced adequate political stability and economic shifts between 1974 and 1978 under the leadership of President Ibrahim al-Hamdi in the north and Salim Rubai Ali in the south towards notable socio-economic development, poverty alleviation, conducive problem-solving environments for internal complexities, and the integration of both Yemeni regions for a novel entity.

Unfortunately, both leaders were murdered on 11 October 1977 and 1978 following military coups that challenged both parties. Yemen demonstrated relative stability between 1979 and 2011, specifically in the north following the oil discovery in 1984. The natural resource offered national income diversification and a negotiation of power with southern Yemen for unity. Nevertheless, the period was linked to predicaments that hampered financial welfare and adequate living standards at individual or social levels. Through political and financial power manipulations by former President Ali Saleh's family members, widespread corruption impeded national recovery efforts.

Both Yemeni regions declared unification in 1990 and finally became a nation recognised as the Republic of Yemen. The integration caused multiple intricacies involving demographic population composition where the tribal system remarkably affected the northern society as opposed to the southern counterpart (urbanisation). Financial complexities emerged as most northern Yemenis were more financially autonomous under the capitalist financial system than the southern population, mainly public sector employees under the Soviet socialist financial system. Lastly, political intricacies involving power congruencies occurred between both governments, specifically with Sana'a as the northern capital city. 
The complexities led to a political downfall and another civil war in the summer of 1993 between North and South Yemen with the removal of Ali Salem al-Baid as the Vice-President of the Republic of Yemen, who became a political refugee. The war adversely impacted both Yemeni regions and worsened financial and social circumstances. Inadequate political crisis management and economic competition from surrounding nations (notably Saudi Arabia) caused the eviction of over a million Yemeni workers from lands due to the support extended to Iraq during the first Gulf War in 1991. Both downfalls instigated financial failure and political ambiguities, resulting in Yemen emerging as one of the poorest and most dangerous nations, harbouring extremists such as Al-Qaeda. Thus, Yemen was acknowledged as one of the first corrupted nations (ranked 176th out of 180 nations) based on Transparency International 2018.

Political crises, multiple failures, and insufficient central authority resulted in the civil war between Houthis (a northern Yemeni tribe bordering southern Saudi Arabia). Thus, they were persecuted and marginalised between 1962 and 2015 by the central government. The Houthis were deemed a threat for three reasons: (a) the tribe belonged to the Sayed family, who ruled the nation for almost seven centuries until 1962. Public recognition would provide the Houthis with power and threaten the present regime; (b) the tribe belonged to Zaidi Shiit with revolutionary perspectives where unfair regimes should be toppled, applying pressure to the Saudi Arabian regime and official sect under the Wahhabi perspective (individuals should adhere to the king despite unfairness); and (c) the past regime ruled following patronage and regionalism that notably deprived the rights of many Yemenis, specifically the Houthis. These aspects explicitly and implicitly influenced security, political, and financial deterioration that ended with the youth revolution in 2011.

Yemenis typically predicted the revolution to assist the country by identifying a discussion platform and reconfiguring the national aim for a united, strong, autonomous, and balanced country. The regional interference from Saudi Arabia and the United Arab Emirates (UAE), who purportedly facilitated a legal government and Iran, who aided the Houthis, resulted in large-scale national and global wars. For example, a civil war occurred between 2015 and 2020 between the legal government (explicitly aided by Saudi Arabia and UAE) and the Houthis, causing a massive national catastrophe and magnifying Yemenis' suffering. The World Bank reported that Yemen is one of the poorest nations in the world, with a Gross Domestic Product (GDP) of 774.3 USD per capita, despite the Yemeni population exceeding 29 million.

Donor organisations have urgently appealed support for Yemen in averting catastrophe. Donor organisations and the World Bank established an independent executive unit to administer grants and financial support under global supervision rather than relying on national administration following the national-scale corruption under President Saleh. For example, the Social Development Fund (SDF) was developed in 1997 to enhance rural area socio-economic development. The SDF development encompassed four primary stages: (a) poverty reduction through entrepreneurial and revenue production activity development, (b) rural area community development through economic service expansion to the most underprivileged categories for enhanced livelihood, (c) social empowerment with social development training for communal and sustainable rural area development, and (d) SFD attempts to expand past-stage activities and facilitate poverty mitigation through development institutions.

Therefore, the Al-Amal Bank was selected in 2009 as an SDF initiative to offer microcredit financing to underprivileged individuals, particularly women. Microcredit financing was not a novel poverty mitigation strategy, as most past studies highlighted Yemeni microcredit financing possibilities and complexities. Nevertheless, the influence of microcredit financing on women empowerment and the subsequent roles in many conservative nations, specifically Yemen, remained unexplored. 


\subsection{Al-Amal Microfinance Bank}

The Al-Amal Microfinance Bank is one of the Yemeni banks specialising in small loan management and financing for low-income and underprivileged individuals, specifically women. The bank intended to catalyse poverty mitigation with microfinancing and small business development to improve work opportunities and enhance fixed-income access rather than relying on government support. Thus, the bank reduces the pressures on government employment amid foreign investment scarcity in Yemen. Al-Amal initiated the pilot phase in late 2008 and formally launched the business in January 2009 after a five-year business plan for extensive economic services (credit, savings, and insurance) in line with the Islamic Sharia regulation.

The bank was established with a capital of 9.3 million USD distributed among three shareholders (45\% Yemeni government shares under SDF, 35\% Arab Gulf Programme for development shares, and 20\% Yemeni and Saudi private sector shares). Primary Al-Amal Bank borrowers encompassed $60 \%$ women as the overall beneficiaries. In 2013, the Al-Amal Bank stated that approximately 34,374 women received microcredits, with 11,501 active women borrowers in 2019. The bank has reportedly covered eight provinces, reaching 223,000 beneficiaries to date. Various products and services (collective and individual loans, Takaful, saving products, and remittance) complemented specific needs to improve efficiency, minimise credit risk, and maximise bank financial sustainability. Collective loans notably entailed the primary product.

\subsection{Al-Amal Solidarity Group}

Group lending denoted one of Al-Amal Bank's primary products for five or more female members or women with blood-related men. A total of 34,374 women beneficiaries were identified, with most members from Sana'a (the capital city of Yemen) in the $2014 \mathrm{Al}-$ Amal annual report. The loan disbursement process was delegated under social collateral where groups of women or women with men were mutually responsible for loan repayment. The collective loan was offered to at least five members in the first stage, with each borrower spearheading an actual current project or have some experience in revenue-producing counterparts. Members were required to attend preparatory and payment meetings for the group's leader and head of fund security selection. Members must essentially reside in the same area without being first-degree relatives (mothers and sisters).

Although two members from the same household can be aided, the individuals must belong to separate groups. Eligible members were required to provide an identification (ID) copy and group guarantee, including members' photos and parents' ID cards. Loans were offered at a minimum of 5000 Riyal that gradually increased to 100,000 Riyal while the loan repayment duration was optional. For example, the maximum loan repayment time was between six and eight months, whereas instalments should be due every 15 days with $2 \%$ savings. Hence, borrowers could repay loans flexibly within the specified period to reduce credit risk. Women were perceived as housewives who engaged in childcare and performed marital and parental duties in many nations, specifically Muslim communities.

In contrast, husbands were the financial navigators of households [17]. Yemeni women lived in patriarchal communities with distinct lifestyles implying "sexual purity" and were typically married off early and bore many children. Poor households reflect large household sizes, inducing household vulnerabilities and substantial financial burdens on husbands and health issues on wives. The gender gap involving Middle Eastern Muslim women remains an unresolved barrier. Many women were denied work opportunities and financial services despite access to education [12], particularly in low-income nations such as Yemen.

Microfinance was acknowledged as a vital developmental instrument to bridge gender inequalities in nations restricted by conventional and religious norms that prioritised maleoriented household decisions and resource controls. Economically, microcredit roles on women empowerment could facilitate women's assets and access to revenue-producing activities. Microfinance impacts on gender equalities and households also surpassed revenue access to encompass financial or social decision-making processes. 
Research in Bangladesh revealed that household decisions, including daily expenses [18] and asset acquisition [19], transformed from the husbands' primary duty to mutual household accountability or personal decision-making among female borrowers from Grameen Bank. Hence, women empowerment was linked to improved life quality, including healthcare decisions [20]. Data from India disclosed that microcredit positively affected health insurance investments among female borrowers [21]. Nevertheless, several studies questioned microfinance capacities towards women empowerment by maintaining that microcredit could be harmful to women, specifically individuals who lose loan control. For example, Ganlea et al. [3] highlighted women empowerment influences on Ghanaian microcredit access and discovered that women empowerment only functioned to a certain extent with insufficient loan control and harassment due to delayed loan repayments.

\subsection{Theoretical Background and Literature Review}

Women have been disregarded and imperilled to male control for many centuries. Today, women empowerment is a worldwide concern, specifically in less developed countries. Solidifying women's economic position is a transformation point to reduce poverty and advance socio-economic development. The emphasis on women has also been attributed to women's nature of investing their incomes in essential household and children expenditures, compared to men who allot their incomes for entertainment solely [10]. The governments of these nations strive to eradicate poverty and empower women by implementing numerous anti-poverty programmes to fight poverty, such as the microfinance policy, for almost thirty years [5].

Through microcredit, empowerment is more effortless [22]. However, no consensus understanding about the empowerment concept is available. Empowerment can be defined as a process or a mechanism by which people, organisations, and communities gain mastery over their affairs [23]. Empowerment is described as processes and outcomes of efforts, which affect an individual's life by influencing decisions [24]. Empowerment can also be observed the individual and community levels. Individual level empowerment refers to a process by which individuals learn to link their goals and ways of achieving them and find connections between their efforts and results [25]. Conversely, community level empowerment can be defined as the process focused on the local community, having mutual respect, group participation, critical reflection, and caring. People lacking an equal share of treasured resources obtain significant access and control over those resources [26].

The empowerment theory of Rappaport [23] states that actions or structures can be empowering. The consequences of these actions and structures result in a level of being empowered. Both processes and outcomes are different in their nature as one standard cannot be applied to people in all contexts $[23,24]$. For example, the empowerment of a young mother is different from that of a widowed middle-aged man. Empowerment varies according to the context and people due to distinct forms of empowerment. In this research, empowerment (dependent variable) changes according to Muslim women's education, income, and age (moderating variables). The empowerment process and outcomes should be critically separated to define the empowerment theory. First, empowering processes entail: gaining control, obtaining required resources, and critically comprehending the social environment. A process is only empowering when individual skills are developed to be independent problem-solvers and decision-makers. Secondly, empowering outcomes mentions the implementation of empowerment to measure individuals' efforts to control their community. Microcredit financing has been acknowledged as an efficient tool for driving women empowerment at economic and social levels.

\subsection{Microcredit and Women Economic Empowerment}

Empowering women via microcredit is a critical factor for women empowerment in developing countries. A randomised control study from India demonstrated that microcredit positively impacts borrowers' income, especially among urban borrowers [27]. Akhter and Cheng [8] confirmed that microcredit improved the livelihood of women in Bangladesh. 
The researchers discovered that rural women who received microcredit had significantly increased economic empowerment levels than women who never received microcredit. Nevertheless, several researchers have proved that microcredit could negatively impact household economic welfare and poverty decline.

Using propensity score matching, Takahashi, Higashikata, and Tsukada [28] summarised that microcredit could not instantaneously affect poverty mitigation when the econometric results were not statistically significant. Augsburg et al. [29] argued that microcredit could negatively affect child schooling, especially when the family preferred households labours. Increasing dependence on microcredit correlated with reduced schooling attendance of teenagers and kids. Nonetheless, these implications are insignificant. Contrastingly, increased microcredit participation caused a significant increase in teen labour [29]. In addition, microcredit was found to have no impact on many countries. Tarozzi et al. [14] concluded that microcredit has no significance on the overall household income in Bosnia and Herzegovina. The findings demonstrated an insignificant positive impact on self-employed income, whereas the figure for wage activities income was significantly negative. Other income indicators, such as remittances and government benefits, were insignificant and negative estimators. Thus, microcredit might not be a significant driver for households to break out from poverty [11].

Additional research undertaken in the Middle East also discovered the impact of microcredit participation. The experience of the less developed countries in the Middle Eastern Region exhibited the positive impact of microfinance on the clients' welfare. For example, Elsafi et al. [5] asserted that microfinance in Sudan has led to declining poverty. However, research in Ethiopia [14] discovered that microcredit positively affects indicators of household income, such as income from self-employment activities and wage, but this is statistically insignificant. Similarly, Ali and Mughal [15] proved no effect of microfinance in poverty reduction in Djibouti.

Contradictory findings may have resulted because microcredit works distinctly in different countries and areas, such as rural or urban, according to population density, attitudes towards debt, group cohesion, enterprise development, financial literacy, financial service providers, and others [30]. Nonetheless, most research corroborated the positive effect on women empowerment in assets and income, although mixed results were found on microfinance's impact [31]. Therefore, the following hypotheses were developed:

Hypotheses H1: Access to microcredit has a significant positive effect on household income.

Hypotheses H2: Access to microcredit has a significant positive effect on household assets.

Hypotheses H3: Access to microcredit has a significant positive effect on personal assets.

\subsection{Microcredit and Women Social Empowerment}

Empowerment is generally recognised as "the expansion in people's ability to make strategic life choices in a context where this ability was previously denied to them" [32]. According to the definition, the ability to make choices could be evaluated in three inter-related dimensions, such as resources (e.g., material, human, or others) or agency (e.g., goals, motivations, and purposes), that individuals incorporate into their acts and achievement that denotes the specific ways of being and doing comprehended by distinct individuals [33,34]. In Muslim societies in Yemen and other nations, daily activities such as interaction within community and family rules outline women's social position and gender-based roles.

Islam laws and cultural norms influence their lives in distinct stages, including their clothes, movement, wedding, divorce, consent for birth control, property rights, inheritance rights, education, employment chances, and decision-making [7]. For instance, a Muslim lady wears a hijab to cover her hair and complies with her husband and obtain his consent before undertaking activities outside the house [35]. Women are observed as homemakers and responsible for child-rearing and fulfil marital and motherly duties, whereas men are accountable for financial and administrative roles in their families. Husbands make domiciliary decisions as they handle and support home expenditures. Supporters of 
women empowerment have highlighted that assisting women financially by providing financial service affects them socially and economically at household and individual levels.

Conversely, women with productive microcredit develop the capability to partake in market activities and obtain independent earnings that assist them in improving life and household quality [8,36]. Additionally, access to microcredit aids women in enhancing their self-respect and in solidifying their status in making decisions at home [9]. Microfinance assistance facilitates women in achieving space and freedom, specifically in leaving their house to manage businesses or visit their acquaintances' homes [35].

The fundamental logic for microfinance asserts that providing financial services to women aids them in becoming self-employed and in obtaining permission to earnings via micro and small businesses. Women with careers have negotiating power in decisionmaking at home, and they travel beyond their house for work and other purposes. Nevertheless, the advantages of women's empowerment in making decisions and decreasing gender inequalities are less apparent. Additionally, microfinance's impact was determined to be mixed positively and negatively. For instance, research by Shohel, Niner, and Gunawardana [37] corroborated that partaking in microfinancing programmes has not transformed gender norms or financially empowered women, as loans for women were extensively handled by men as stipulated by core and unchanged patriarchal gender norms.

Despite the contradicting literature, microcredit financing has been an effective development tool for women empowerment. Microcredit's role in women empowerment goes beyond the household economy and wellbeing empowerment to include social empowerment and women's role in making decisions at home. The literature suggests that microcredit allows women to obtain independent earnings and contributes to their home income and expenses [22,38]. According to Al-shami et al. [7], access to microcredit has a significant impact on the ability of Malaysian women to share a household, business decisions, and loans. In addition, microcredit enables women to participate in their home earnings and play a crucial role in making decisions at home, involving asset purchases, family management, and children [19]. Despite the rich stream literature on microcredit's impact on women empowerment comprising positive, negative, and no impact, literature related to the less developed countries in the Middle Eastern Region is scarce. Therefore, the following hypotheses were established:

Hypotheses H4: Access to microcredit has a significant positive effect on women's mobility decisions.

Hypotheses H5: Access to microcredit has a significant positive effect on decisions regarding children.

Hypotheses H6: Access to microcredit has a significant positive effect on household expenditure.

Hypotheses H7: Access to microcredit has a significant positive effect on household asset acquisition.

Hypotheses H8: Access to microcredit has a significant positive effect on business decisions.

Hypotheses H9: Access to microcredit has a significant positive effect on the loan decision.

\section{Methodology}

This research aimed to investigate microcredit impacts on Yemeni women empowerment with a two year panel dataset under the Al-Amal Bank. Financial and social empowerment evaluations were adopted from Fofana, Antonides, Niehof, and Ophem [39] and Al-shami et al. [7] and were employed. A cross-sectional survey with female loan applicants (married women) as respondents was undertaken in January 2014. Notably, this research corresponded to previous studies on coping mechanisms in the Yemeni setting.

\subsection{Study Setting and Microfinance Institution MFI Coverage}

Sana'a was purposively selected as the research context from three branches (AlWahda, Al-Thawra, and Al-Tahrir) as most Al-Amal beneficiaries resided in the area. As microcredit financing was not a novel phenomenon in Sana'a, the exposure facilitated positive results concerning the Yemeni population. Although Al-Amal Bank was highly experienced in microcredit financing, most beneficiaries hailed from urban areas, particularly 
Sana'a. Hence, studies in rural areas proved challenging due to poor conditions and a lack of control group members as microcredit impact assessments required group members (borrowers) for a minimum of two years.

\subsection{Data Gathering}

This study strived to investigate microcredit impacts under the Al-Amal Bank on Yemeni women empowerment. The research sample was determined at the beginning of September 2013 during the loan application process by Al-Amal Bank. A total of 836 women passed the initial process with loan receiving eligibility. The bank approved 425 of the 836 applicants and began receiving loans in January 2014 as the required prerequisites were fulfilled. Contrarily, 411 applications were postponed for another two years because: (1) the women were new to the selected location and could not conveniently identify members for group formation; (2) loan sanctions proved risky following conflicting information with most applicants not being homeowners or socially renowned; and (3) other internal considerations, including bank capacity. A collaboration with Al-Amal Bank officers in December 2014 facilitated the information access of women applicants in the fourth quarter of 2013 from three primary Al-Amal branches (Al-Wahda, Al-Thawra, and Al-Tahrir). The women with sanctioned loans but who did not respond to the study survey during the application process in January 2014 were invited. However, only 391 borrowers who began borrowing in February 2015 accepted the study invitation (treatment group) (see Table 1).

Table 1. Data collection.

\begin{tabular}{|c|c|c|c|c|c|c|c|}
\hline \multirow{2}{*}{ Group } & \multirow{2}{*}{ Description } & \multicolumn{3}{|c|}{ Interview Survey January/2014 } & \multicolumn{3}{|c|}{ Interview Survey December/2015 } \\
\hline & & Invited & Responded & Valid & Invited & Responded & Valid \\
\hline $\begin{array}{l}\text { Treatment } \\
\text { Group }\end{array}$ & $\begin{array}{l}\text { Women who began receiving } \\
\text { loans from Al-Amal from } \\
\text { February } 2015 \text { to } \\
\text { December } 2016 .\end{array}$ & 425 & 391 & 391 & 331 & 327 & 321 \\
\hline $\begin{array}{l}\text { Control } \\
\text { Group }\end{array}$ & $\begin{array}{l}\text { Eligible women with postponed } \\
\text { applications (for the previously } \\
\text { mentioned reasons) that were } \\
\text { subsequently accepted in the } \\
\text { fourth quarter of } 2016 .\end{array}$ & 411 & 339 & 339 & 313 & 299 & 294 \\
\hline & Total & 836 & 730 & 730 & 644 & 626 & 615 \\
\hline
\end{tabular}

Additionally, 339 eligible non-borrowers who failed to meet the prerequisites participated in the study (control group). The borrowers and non-borrowers were invited again in December 2015. They answered the altered survey questions before and after borrowing to compare the changes between borrowers and non-borrowers. Interestingly, active borrowers (treatment group) who continued borrowing from early 2015 to December 2015 dropped to 331 with an estimated dropout rate of $15.4 \%$ following residential changes. Additionally, 327 applicants participated in the survey with 321 valid questionnaires. A total of 313 women whose applications were postponed in 2013 and subsequently approved in the fourth quarter of 2015 were invited to answer the survey. However, only 299 accepted the invitation, with 294 valid responses.

\subsection{Propensity Score Matching}

The primary research objective was to investigate the microcredit impact of Al-Amal Bank on women empowerment and comprehend how Al-Amal microcredit access affected poverty alleviation. The propensity score matching was employed to alleviate the impact of intangible aspects affecting borrowers' performance (entrepreneurial skills) as self-selection bias might occur following borrowers' attributes before engaging in the microcredit programme. The propensity score matching also demonstrated the conditional likelihood of 
receiving treatment, supposed pre-treatment, or exogenous member attributes [40]. Thus, the equation developed was:

$$
P(X)=\operatorname{Pr}[D=1 / X]=E[D / X]
$$

$D$ denoted the borrower indicator, whereas $D=1$ implied borrowers who received loans (treatment group) with particular attributes (education, age, experience, and household size). Notably, $D=0$ denoted no borrowers and individuals without loans (the control group). Conversely, $X$ implied a pre-intervention multidimensional vector feature. The propensity score matching reflected the index variable that summarised the pre-treatment attributes for each theme to enable matching.

On another note, $D=0$ denoted no borrowers and individuals yet to receive loans (control group). The $X$ indicator implied the multidimensional vector of the pre-intervention attribute. Furthermore, the propensity score matching denoted the index variable that summarised the pre-treatment attributes of each theme that facilitated matching. The average treatment effect (ATE) on the average treatment effect on treated (ATT) could be subsequently formulated upon computing the propensity score as follows:

$$
\begin{gathered}
\mathrm{ATT}=\left\{Y_{i}^{1}-Y_{i}^{0} \mid \mathrm{D}=1\right\} \\
\mathrm{ATT}=\mathrm{E}\left[\mathrm{E}\left\{Y_{i}^{1}-Y_{i}^{0} \mid \mathrm{D}_{\mathrm{i}}=1, \mathrm{p}(\mathrm{x})\right\}\right] \\
\mathrm{ATT}=\mathrm{E}\left[\mathrm{E}\left\{Y_{i}^{1} \mid \mathrm{D}_{\mathrm{i}}=1, \mathrm{p}(\mathrm{x})\right\}\right. \\
\left.-\mathrm{E}\left\{Y_{i}^{0} \mid \mathrm{D}_{\mathrm{i}}=0, \mathrm{p}(\mathrm{X})\right\} \mid \mathrm{D}=1\right]
\end{gathered}
$$

$Y_{i}^{1}$ and $Y_{i}^{0}$ specifically denoted potential treatment consequences with no care in the dual counterfactual state of affairs. The propensity score matching technique was employed to readjust initial adjustments between the care and control classes by matching respondents to controls in measuring attributes against similar propensity ratings. Notably, the propensity score matching encompassed dual anticipations: (1) determining the exogenous aspects that simultaneously impacted the patient and outcome treatment engagement influences; and (2) ensuring that treatment and control group members were similar before treatment. The respondents' comparative measurable elements were utilised as monitoring and treatment classes [41]. The ATE denoted the readjustment between the average impacts on treated and untreated people, and a stepwise was utilised for ATE assessment. A propensity score apprehending the possibility of being treated with a set of exogenous attributes was analysed initially through probit regression for every group. The individuals were grouped following forecasted engagement potential.

All control samples were matched to each treated sample through Kernel Matching. Individuals close to the treated sample were allotted the heaviest weight. Fofana et al. [39] affirmed the advantage of supporting low variance as the weighted average utilised to achieve counterfactual outcomes for all control group respondents. Subsequently, a $t$-test for variances in the pre-treatment variables between the control and treated classes for comparability following propensity score matching and event-matching was undertaken at the third stage. Respondents' schooling, marital status, age, number of family earners, household size, company ownership, single household members, and propensity score generation experiences influenced potential microcredit attainment. The mentioned elements more likely impacted investor possibilities and results simultaneously.

\subsection{Measurements}

\subsubsection{Income}

High household income conveniently forecasts gradual household changes as an essential indicator. For example, microcredit access enabled most unemployed Yemenis to establish businesses and generate revenues. Income calculation was extensively and reliably employed as a predictor of microfinance impact assessment on household wellbeing and poverty eradication [37]. As per Al-shami et al. [10], the microcredit effect on women 
economic empowerment was measured through household income before and after access to microcredit.

\subsubsection{Assets}

Assets denoted productive household aspects that involved remarkably high consumption and investment. For example, electrical equipment, electronics, household products, and company properties are classified as assets with monetary values. Multiple studies employed the metric and emphasised that poor microcredit borrowers, specifically women, might have asset development possibilities [7].

\subsubsection{Decision-Making Empowerment}

Kabeer [42] stated that income or financial service access (loans) did not imply current women empowerment as per the notion that empowerment denoted women's capacity to manage personal lives and engage in household decision-making. Hence, this study examined the social alterations in women's households following microcredit access compared to women without access, in line with Shohel et al. [2]. This study emphasised questions that elaborated on decision-making processes with specific questions on specific scopes. Six survey predictors evaluated household decision-making impacts on a four-point scale (1 = My family members, 2 = My husband, 3 = My husband and myself, and $4=$ Myself). Household decisions were assessed under six measurements in the study context, comprising "health expenditure", "daily food expenditure", "asset purchase", "birth control", "resource control", and "external mobility". Multiple studies extensively employed the assessments [7,39].

\section{Data Analysis and Result}

\subsection{Demographic and Socio-Economic Characteristics}

Table 2 presents the demographic information of Al-Amal microcredit borrowers and non-borrowers. The 615 samples were categorised into 321 borrowers and 294 nonborrowers. The borrowers consisted of 171 respondents (treatment group) in the matched sample column, whereas 269 respondents were non-borrowers (control group). The borrowers were relatively younger and more educated than the non-borrowers. Additionally, borrowers with large households, few family income producers, and highly experienced borrowers-cum-homeowners were more inclined to receive the Al-Amal loan.

Table 2. Socio-economic and demographic characteristics.

\begin{tabular}{|c|c|c|c|c|c|c|}
\hline \multirow{2}{*}{$\begin{array}{c}\text { Numbers } \\
\text { Demographic }\end{array}$} & \multicolumn{3}{|c|}{ Unmatched (175) } & \multicolumn{3}{|c|}{ Matching (440) } \\
\hline & $\begin{array}{l}\text { Borrowers } \\
\quad(150)\end{array}$ & $\begin{array}{c}\text { Non-Borrowers } \\
\text { (25) }\end{array}$ & $t$-Test & $\begin{array}{l}\text { Borrowers } \\
\text { (171) }\end{array}$ & $\begin{array}{c}\text { Non-Borrowers } \\
\text { (269) }\end{array}$ & $t$-Test \\
\hline Age & 34.8 & 34.3 & 0.28 & 33.59 & 34.1 & 0.51 \\
\hline Married & 49 & 24 & $6^{* *}$ & 86 & 142 & 0.61 \\
\hline Single & 101 & 1 & $5.9^{* * *}$ & 85 & 127 & 0.61 \\
\hline Education & 10.4 & 5.9 & $8^{* * *}$ & 9.45 & 8.94 & 1.9 \\
\hline Household Size & 5 & 3.6 & $5.8^{* * *}$ & 4.74 & 4.7 & 0.73 \\
\hline Earner Income & 0.85 & 0.6 & 1.78 & 0.655 & 0.658 & 0.96 \\
\hline Single Household Life & 0.44 & 0.24 & 1.89 & 0.36 & 0.32 & 0.72 \\
\hline Own Business & 0.63 & 0.16 & $4.7^{* * *}$ & 0.46 & 0.44 & 0.72 \\
\hline Experience & 0.63 & 0.2 & $4.5^{* * *}$ & 0.6 & 0.51 & 0.09 \\
\hline
\end{tabular}

\subsection{Dynamics of Borrower Access to MFI Credit}

The probit regression model was utilised to investigate the impacts of borrowers' socio-economic and demographic attributes that were the significant deterrents underlying Al-Amal loan access for productive aims (e.g., business expansion or incorporating new activities into current businesses). Forecasting the probit model output was a typical 
initiative in all samples that Al-Amal obtained through the dependent variable following the implemented banking strategy. As shown in Table 3, the likelihood of the ratio chisquare of 777.38 with a $p$-value of 0.0001 indicates that the model is statistically significant and more accurate than a model with no predictors. In addition, the Pseudo $R^{2}$ value obtained for each endogenous variable is 0.23 , which is greater than 0.2 and deemed a perfect fit [43].

Table 3. Probit output on Al-Amal microcredit access dynamics.

\begin{tabular}{|c|c|c|c|}
\hline Variables & Coefficient & S.E. & Z-Score \\
\hline Age & -0.135 & 0.092 & 0.874 \\
\hline Age Square & 0.002 & 0.001 & 1.002 \\
\hline Gender & 0.231 & 0.178 & 1.260 \\
\hline Marital Status & -0.453 & 0.205 & 0.635 * \\
\hline Years in Education & 0.159 & 0.033 & $1.2^{* * *}$ \\
\hline Household Size & 0.149 & 0.073 & $1.16^{*}$ \\
\hline Income Earners & 0.361 & 0.140 & $1.4^{* *}$ \\
\hline Business Ownership & 0.408 & 0.176 & $1.5 *$ \\
\hline House Ownership & 0.526 & 0.192 & $1.69^{* *}$ \\
\hline Experience & 0.486 & 0.185 & $1.6^{* *}$ \\
\hline Constant & -0.691 & 1.581 & 0.501 \\
\hline Number of Jobs & & 715 & \\
\hline $\mathrm{LR} \mathrm{Chi}^{2}$ & & $74^{* * *}$ & \\
\hline Log-likelihood & & 777.38 & \\
\hline Pseudo $R^{2}$ & & 0.23 & \\
\hline
\end{tabular}

According to Table 3, group members originated from the same culture or could even be relatives. For example, the $\mathrm{z}$ single sisters could more likely gain microcredit access for business expansion for parents or friends than could married women. Highly educated borrowers applied for Al-Amal microcredit following financial imbalances that prevented work opportunities, while young women obtained microcredit for business expansion activities and high income. Borrowers with large households and other income earners from the same family also tended to receive Al-Amal microcredit. Family members facilitated and inspired other household members towards employment through competition and collaboration. Furthermore, business owners who were homeowners with business experiences tended to obtain Al-Amal Bank loans as per the bank strategy of approving loans for company expansion, household sustenance, and low default risk.

The coefficient of education, household size, income earners, business ownership, house ownership and women business experience were positive and significant associated with accessing to microcredit. These results revealed that variables with positive signs indicate that their higher values increase the chances that the women have to access credit and vice versa. The chi square estimate of 74 is highly significant. As a measure of goodness of fit, it shows that the data set fit the regression line to a reasonably high level.

\subsection{Microcredit Impact of Income and Asset}

Table 4 presents Al-Amal microcredit impacts on assets and income upon accounting for potential bias. The effects involved product changes within respondent groups (borrowers and non-borrowers) with and without Al-Amal loans. A specific result proposed that Al-Amal loan attainment positively affected specific results. Additionally, positive revenue alterations between the matched groups of women borrowers with Al-Amal loans and those without the loans were positive. On average, borrowers earned more revenue compared to non-borrowers, denoting that microcredit borrowers experienced increased revenue production. 
Table 4. Microcredit impact on male income and asset.

\begin{tabular}{|c|c|c|c|c|c|c|c|c|}
\hline & \multicolumn{4}{|c|}{ Unmatched } & \multicolumn{4}{|c|}{ Matched } \\
\hline & $\begin{array}{l}\text { Borrowers } \\
\quad 150\end{array}$ & $\begin{array}{c}\text { Non-Borrowers } \\
25\end{array}$ & Diff. & $t$. & $\begin{array}{c}\text { Borrowers } \\
171\end{array}$ & $\begin{array}{c}\text { Non-Borrowers } \\
269\end{array}$ & Diff. & $t$ \\
\hline Monthly Income & 21,750 & 15,000 & 6750 & $2.5^{* *}$ & 21,011 & 19,419 & 1592 & $2.9^{* *}$ \\
\hline Personal Assets & 71,500 & 62,000 & 9500 & 1.3 & 69,802 & 66,370 & 3432 & 1.5 \\
\hline Household Assets & 39,414 & 34,167 & 5247 & 0.86 & 38,286 & 34,118 & 4168 & $3.1^{* *}$ \\
\hline
\end{tabular}

** $p<0.01$.

Undeniably, microcredit financing is an essential developmental instrument that significantly alleviated poverty and enhanced household welfare in line with [13,39]. Moreover, borrowers' household assets were remarkably higher than non-borrowers' assets, as women in charge of households preferred to invest company returns in household expenses than personal assets [7]. Nonetheless, no remarkable variances were identified between personal assets among borrowers and non-borrowers.

\subsection{Decision-Making Power}

Table 5 illustrates the shift between women with Al-Amal microcredit access and their counterparts without access in the household decision-making cycle. Resultantly, propensity score matching implied that household decisions proved higher among women with microcredit access, such as regular or small purchases involving children's school expenses and household expenditure. Similarly, Al-Amal microcredit exposure positively impacted women empowerment in households and children's school expenses. Women with microcredit access experienced successful small business development and highincome access, resulting in bargaining powers in household decisions.

Table 5. Household decision-making.

\begin{tabular}{|c|c|c|c|c|c|c|c|c|}
\hline Household Decisions & & Unmatched & & & & Matched & & \\
\hline $\mathbf{N}$ & $\begin{array}{l}\text { Borrowers } \\
\text { (150) }\end{array}$ & $\begin{array}{c}\text { Non-Borrowers } \\
\text { (25) }\end{array}$ & Diff. & $t$. & $\begin{array}{l}\text { Borrowers } \\
\text { (171) }\end{array}$ & $\begin{array}{c}\text { Non-Borrowers } \\
\text { (269) }\end{array}$ & Diff. & $t$. \\
\hline Mobility & 2.75 & 2.734 & 0.016 & 0.04 & 2.73 & 2.46 & 0.27 & 1.4 \\
\hline Children & 3.08 & 2.53 & 0.55 & $2.3^{*}$ & 3.14 & 2.64 & 0.5 & $3.3^{* *}$ \\
\hline Expenditure & 3.39 & 2.89 & 0.5 & $2.1^{*}$ & 3.4 & 3.04 & 0.36 & 2.45 * \\
\hline Asset & 2.63 & 2.21 & 0.42 & 1.6 & 2.99 & 2.72 & 0.27 & 1.8 \\
\hline Business & 2.6 & 2.3 & 0.3 & 1.7 & 2.765 & 2.37 & 0.399 & 1.7 \\
\hline Loan & 2.7 & 2.16 & 0.54 & 1.68 & 3 & 2.7 & 0.3 & 1.88 \\
\hline
\end{tabular}

The findings corresponded to Al-Shami et al. [44] from Malaysia, Akhter and Cheng [8] from Bangladesh and West Africa, and Fofana et al. [39] in asserting that microcredit impacts on household decision-making. No significant changes were observed in women borrowers' and non-borrowers' external mobility (decision-making outside home grounds). Orthodox communities representing Yemeni culture maintained that inter-gender socialisation contradicted morality and traditions restricting female mobility. No significant gaps were identified in business decision-making between female lenders and non-borrowers adhering to conventional and patriarchal norms where either husbands or fathers' children dominated decision-making authorities that impacted women's resource management role. The findings corresponded to Akhter and Cheng [8], who found that Ghanaian microcredit did not substantially impact women with less autonomy over the received loans, causing loss of loan control and male dominance in manipulating women as proxies for loan attainment.

A group discussion was performed with five female members (leaders of five groups) during the loan repayment period at the Al-Hasabah branch in Sana'a in November 2015 for a sound comprehension of how microcredit access impacted women empowerment. 
Microcredit financing was unanimously conceded to positively impact household welfare, such as food, childcare, and health. The direct microcredit impact on household welfare is based on the fact that most female borrowers hailed from underprivileged categories and utilised the income for household expenses. The research outcome corresponded to Al-shami et al. [7], where the microcredit financing offered by Amanah Ikhtiar Malaysia (AIM) positively impacted Malaysian household welfare.

Microcredit impact on household expenses relied on loan size and group members' cooperation. For example, Borrower A stated that:

"I managed to have access to good loan size. My group member and I have a good relationship; we have an agreement whereby I receive the first loan, and the second one will be given to another member until we finish all members. This provided me with an opportunity to improve my business and gain more profit which allows me to enrol my son in private school".

Similarly, Hussain et al. [36] discovered that the loan size offered by Pakistani microcredit institutions impacted poverty mitigation. Contrarily, female resource control involving loans and business decisions were weak. For example, Borrower B, who worked at a bakery, stated as follows:

"My son is the one who controls and manages the loan. It is because I do not know how to record the transactions and allocate the instalments, and I do not know how to market my business".

The borrower's response was negative when questioned if she underwent business development training by Al-Amal Bank or other financial institutions. Likewise, Borrower C stated as follows: "My husband is the one who controls the loan".

Nevertheless, the reasons involved a mix of poor business management (financial literacy) and family rituals as husbands possessed household decision-making authority. Some husbands and female relatives utilised female family members as proxies for loan attainment in some cases. For example, Woman C implied that microcredit access from AlAmal Bank resembled arranged marriages where women obtain loans to be transferred to brothers or husbands. One member specifically utilised the loan to purchase a motorcycle for her brother, who eventually stopped paying the instalments. The member had to sell her gold for loan repayment. The situation reflected a common challenge as women were employed as loan attainment proxies by male family members. According to AlShami et al. [35], women were compelled to take accountability, specifically in the absence of microcredit insurance [7].

\section{Study Implications}

\subsection{Theoretical Contribution}

Women empowerment is regarded as an effective strategy to alleviate poverty, particularly in less developed countries. International development agencies and governments put faith in microcredit financing as the vehicle to drive women empowerment and poverty reduction. However, the literature reported a mix of positive, negative, and no impact results because microfinance works differently in distinct nations according to varying demographics, social factors and microcredit institutions. Therefore, as the first study in the Yemeni context, this study bridges the gap by providing empirical evidence on the microcredit impact on women empowerment in less developed countries, notably Yemen.

Several studies in the literature have investigated the microcredit effect on women empowerment in the Middle East Region, such as Sudan [5], Ethiopia [14], and Djibouti [15]. However, these studies arrived at mixed results between positive and no impact. In addition, these studies used household income as an indicator for measuring the microcredit effect, leaving a gap in how the microcredit financing interaction influences the process and outcome of women empowerment because women in conventional environments can access income but do not gain control of their decisions. This study contributes to 
empowerment theory by examining microcredit financing on the process and outcome of women empowerment.

This research produces new evidence on how access to microcredit influences women's empowerment through access to income and improving household assets' value. Conversely, this research measures $\mathrm{Al}$-Amal microcredit's effect on the various aspects of women's social empowerment, particularly household decisions. Yemen is a Muslim country where social and family traditions significantly influence women attributes and lifestyles. However, women empowerment literature on Yemen, and Muslim societies generally, lacks sufficient studies. Therefore, the findings show that microcredit financing with entrepreneurship training is associated with women empowerment in Yemen, a Muslim country with high social and family traditions.

\subsection{Practical Contribution}

The research findings provide vital benefits for policymakers, academicians, female clients, and other microfinance practitioners. For state level policymakers, the findings corroborated that the effectiveness of Al-Amal Bank's intervention programme in the economic empowerment of women's household income and assets. Additionally, for bank level policymakers, the results denote the effectiveness of the implemented programme in women economic empowerment, mainly if the client obtains a massive volume loan. Al-Amal Bank should continuously provide various microfinance products to women from low-income households based on the reported findings. The findings also imply that microfinancing programmes play a critical role when borrowers receive a considerable loan amount. Therefore, the Al-Amal Bank should increase loan sizes to improve the client's living standard and mitigate poverty.

However, this research reveals that microcredit by Al-Amal Bank has a limited effect on women social empowerment in household and business levels, as husbands still control decisions. Policymakers should diversify services by including skills development training, particularly in entrepreneurship and personality development, to improve Al-Amal Bank microcredit. Diversifying the services is essential in enabling women in less developed countries, including Yemen, to be more independent in operating businesses, which is the critical driver for accessing income and participating in household decisions.

As Yemen is one of the poorest countries in the Middle East and has witnessed unprecedented challenges due to ongoing war, this study uncovers how to transfer poverty reduction and women empowerment from aid subsidies to autonomy development. The outcome demonstrates that access to microcredit financing provided by Al-Amal Bank to women improves household income and asset values. Therefore, the international aid agencies and government policymakers are recommended to support Al-Amal microcredit to mitigate the effect of the ongoing war on poverty and unemployment.

\section{Conclusions and Future Research Limitation}

The findings highlighted that microcredit had a minimal effect on women empowerment, although microcredit remarkably affected financial impacts on household income and asset valuation. Multiple external and internal factors (group or family members) and female attributes predictably hampered women empowerment in Arabian nations. Thus, future studies could examine specific triggers that hamper women empowerment. The significant finding of this study suffers from several limitations that can be addressed in future research. First, this research investigates microcredit financing impact on two financial assessments (revenues and properties) and social decision-making. However, integrating other measures, such as sustainability and innovative development for micro and small enterprises, has proved essential [45]. Thus, future studies should emphasise how microcredit provision influenced microenterprise sustainability and expansion as poverty mitigation intermediaries. The findings cannot be generalised to other countries, as this study was conducted in Yemen because the women empowerment concept differed across locations due to multiple factors, such as literacy degree, ethnicity, cultural norms, and 
family rules. Therefore, examining the microcredit effect in the underdeveloped countries in the Middle East and the Horn of Africa is recommended for future research.

This study focused on evaluating microcredit impact on women empowerment using specific economic and social measurements at individual and household levels. Nevertheless, future studies can extend the study scope by including a broader range of women empowerment measures at the community level. In addition, microcredit effects depend on the microcredit product, but this study solely focused on accessing microcredit provided by Al-Amal Bank. Future researchers should implore supplement determents, such as nonfinancial services and loan attributes influencing micro and small enterprises' sustainability by controlling the effect before and after access to microcredit.

Author Contributions: Data curation, S.A.A.-s. and M.A.-s.; formal analysis, A.A.M.; funding acquisition, N.R.; methodology, A.A.M.; resources, N.R. and M.A.-s.; writing-original draft, S.A.A.-s. All authors have read and agreed to the published version of the manuscript.

Funding: This research received no external funding.

Institutional Review Board Statement: Local ethics committees (Universiti Teknikal Malaysia Melaka) ruled that no formal ethics approval was required in this particular case. This study has been performed in accordance with the Declaration of Helsinki.

Informed Consent Statement: Informed consent for participation was obtained from respondents who participated in the survey. The respondents who participated in the survey, were asked to read the ethical statement (There is no compensation for responding nor is there any known risk. To ensure that all information will remain confidential, please do not include your name. Participation is strictly voluntary and you may refuse to participate at any time) and proceed only if they agree. No data was collected from anyone under 16 years old.

Data Availability Statement: Not applicable.

Conflicts of Interest: The authors declare no conflict of interest.

\section{References}

1. Khan, W.; Shaorong, S.; Ullah, I. Doing business with the poor: The rules and impact of the microfinance institutions. Econ. Res.-Ekon. Istraživanja 2017, 30, 951-963. [CrossRef]

2. Parekh, N.; Ashta, A. An institutional logics perspective to evolution of Indian microcredit business models. Strat. Change 2018, 27, 313-327. [CrossRef]

3. Ganle, J.K.; Afriyie, K.; Segbefia, A.Y. Microcredit: Empowerment and Disempowerment of Rural Women in Ghana. World Dev. 2015, 66, 335-345. [CrossRef]

4. Al-Shami, S.S.A.; Majid, I.; Mohamad, M.R.; Rashid, N. Household welfare and women empowerment through microcredit financing: Evidence from Malaysia microcredit. J. Hum. Behav. Soc. Environ. 2017, 27, 894-910. [CrossRef]

5. Elsafi, M.H.; Ahmed, E.M.; Ramanathan, S. The impact of microfinance programs on monetary poverty reduction: Evidence from Sudan. World J. Entrep. Manag. Sustain. Dev. 2020, 16, 30-43. [CrossRef]

6. Phan, C.T.; Sun, S.; Zhou, Z.Y.; Beg, R. Does microcredit increase household food consumption? A study of rural Vietnam. J. Asian Econ. 2019, 62, 39-51. [CrossRef]

7. Al-Shami, S.S.A.; Razali, R.M.; Rashid, N. The Effect of Microcredit on Women Empowerment in Welfare and Decisions Making in Malaysia. Soc. Indic. Res. 2018, 137, 1073-1090. [CrossRef]

8. Akhter, J.; Cheng, K. Sustainable Empowerment Initiatives among Rural Women through Microcredit Borrowings in Bangladesh. Sustainability 2020, 12, 2275. [CrossRef]

9. Tundui, C.S.; Tundui, H.P. Performance drivers of women-owned microcredit funded enterprises in Tanzania. Int. J. Gend. Entrep. 2020, 12, 211-230. [CrossRef]

10. Al-Shami, S.; al Mamun, A.; Sidek, S.; Rashid, N. Causes of failure among Malaysian female entrepreneurs: A qualitative case study of Malaysian microcredit borrowers. Qual. Res. Financ. Mark. 2019, 12, 43-71. [CrossRef]

11. Dao, N.D. Does the microcredit intervention change the life of the low- and middle-income households in rural Vietnam? Evidence from panel data. World Dev. Perspect. 2020, 20, 100259. [CrossRef]

12. Cull, R.; Demirgüç-Kunt, A.; Morduch, J. Microfinance Meets the Market. J. Econ. Perspect. 2009, 23, 167-192. [CrossRef]

13. Salia, S.; Hussain, J.; Tingbani, I.; Kolade, O. Is women empowerment a zero sum game? Unintended consequences of microfinance for women's empowerment in Ghana. Int. J. Entrep. Behav. Res. 2018, 24, 273-289. [CrossRef]

14. Tarozzi, A.; Desai, J.; Johnson, K. The Impacts of Microcredit: Evidence from Ethiopia. Am. Econ. J. Appl. Econ. 2015, 7, 54-89. [CrossRef] 
15. Ali, M.A.; Mughal, M. Microfinance and Poverty Reduction: Evidence from Djibouti. Available online: https://hal-univ-pau. archives-ouvertes.fr/hal-02282359 (accessed on 8 May 2021).

16. Cigar, N. South yemen and the ussr: Prospects for the Norman Cigar. Middle East J. 1985, 39, 775-795.

17. Syed, J.; Özbilgin, M.; Torunoglu, D.; Ali, F. Rescuing gender equality from the false dichotomies of secularism versus shariah in Muslim majority countries. Women's Stud. Int. Forum 2009, 32, 67-79. [CrossRef]

18. Schuler, S.R.; Hashemi, S.M. Credit Programs, Women's Empowerment, and Contraceptive use in Rural Bangladesh. Stud. Fam. Plan. 1994, 25, 65. [CrossRef]

19. Al Shami, S.S.A.; Muhamad, M.R.; Majid, I.; Rashid, N. Women's entrepreneurs' micro and small business performance: Insights from Malaysian microcredit. Int. J. Entrep. Small Bus. 2019, 38, 312. [CrossRef]

20. Jennings, L.; Na, M.; Cherewick, M.; Hindin, M.; Mullany, B.; Ahmed, S. Women's empowerment and male involvement in antenatal care: Analyses of Demographic and Health Surveys (DHS) in selected African countries. BMC Pregnancy Childbirth 2014, 14, 1-11. [CrossRef] [PubMed]

21. Rai, A.; Ravi, S. Do Spouses Make Claims? Empowerment and Microfinance in India. World Dev. 2011, 39, 913-921. [CrossRef]

22. Asad, A.; Hameed, W.U.; Irfan, M.; Jiang, J.; Naveed, R.T. The Contribution of Microfinance Institutes in Women-Empowerment and role of Vulnerability. Rev. Argent. Clín. Psicol. 2020, XXIX, 223-238.

23. Rappaport, J. Terms of empowerment/exemplars of prevention: Toward a theory for community psychology. Am. J. Community Psychol. 1987, 15, 121-148. [CrossRef]

24. Zimmerman, M.A.; Warschausky, S. Empowerment theory for Rehabilitation research: Conceptual and methodological issues. Rehabil. Psychol. 1998, 43, 3. [CrossRef]

25. Landau, J.; Mittal, M.; Wieling, E. Linking Human Systems: Strengthening Individuals, Families, And Communities in the Wake of Mass Trauma. J. Marital. Fam. Ther. 2008, 34, 193-209. [CrossRef] [PubMed]

26. Albers, E.C.; Paolini, N. The dual face of empowerment: A model for cooperative resource building. J. Sociol. Soc. Welf. 1993, 4, 99-109.

27. Aragón, F.M.; Karaivanov, A.; Krishnaswamy, K. Credit lines in microcredit: Short-term evidence from a randomized controlled trial in India. J. Dev. Econ. 2020, 146, 102497. [CrossRef]

28. Takahashi, K.; Higashikata, T.; Tsukada, K. The Short-Term Poverty Impact of Small-Scale, Collateral-Free Microcredit in Indonesia: A Matching Estimator Approach. Dev. Econ. 2010, 48, 128-155. [CrossRef]

29. Attanasio, O.; Augsburg, B.; De Haas, R.; Fitzsimons, E.; Harmgart, H. The Impacts of Microfinance: Evidence from Joint-Liability Lending in Mongolia. Am. Econ. J. Appl. Econ. 2015, 7, 90-122. [CrossRef]

30. Al-shami, S.S.A.; Muhammad, M.R.; Rashid, N. The Effect of Microcredit on Women Household Decisions Making and Resource Controlling in Malaysia. Soc. Indic. Res. 2018, 121, 21.

31. Debnath, D.; Rahman, S.; Acharjee, D.C.; Latif, W.U.; Wang, L. Empowering Women through Microcredit in Bangladesh: An Empirical Study. Int. J. Financial Stud. 2019, 7, 37. [CrossRef]

32. Kabeer, N. Conflicts over credit: Re-evaluating the empowerment potential of loans to women in rural Bangladesh. World Dev. 2001, 29, 63-84. [CrossRef]

33. Aggarwal, S.; Kumar, P.; Garg, V. Empowering SHGs Women through Micro-finance in Uttar Pradesh. Int. J. Law Manag. 2020, 62, 591-606. [CrossRef]

34. Akter, M.F.; Nayeem, A.R.; Didar, A.H. Correlating Women Empowerment with Micro Finance in a Small Village in Bangladesh by Using Statistical Methodology. South Asian J. Soc. Stud. Econ. 2021, 9, 19-27. [CrossRef]

35. Al-Shami, S.S.A.; Razali, M.M.; Majid, I.; Rozelan, A.; Rashid, N. The effect of microfinance on women's empowerment: Evidence from Malaysia. Asian J. Women's Stud. 2016, 22, 318-337. [CrossRef]

36. Hussain, J.; Mahmood, S.; Scott, J. Gender, Microcredit and Poverty Alleviation in a Developing Country: The Case of Women Entrepreneurs in Pakistan. J. Int. Dev. 2019, 31, 247-270. [CrossRef]

37. Shohel, T.A.; Niner, S.; Gunawardana, S. How the persistence of patriarchy undermines the financial empowerment of women microfinance borrowers? Evidence from a southern sub-district of Bangladesh. PLoS ONE 2021, 16, e0250000. [CrossRef]

38. Alam, P.; Azad, I. Impact of Microfinance on Income and Employment of Women in Jigiga, Ethiopia. Int. J. Econ. Bus. Adm. 2021, IX, 373-381. [CrossRef]

39. Fofana, N.B.; Antonides, G.; Niehof, A.; van Ophem, J.A.C. How microfinance empowers women in Côte d'Ivoire. Rev. Econ. Househ. 2015, 10, 1-19.

40. Rosenbaum, P.R.; Rubin, D.B. The central role of the propensity score in observational studies for causal effects. Biometrika 1983, 70, 41-55. [CrossRef]

41. Heckman, J.J. Sample Selection Bias as a Specification Error. Econometrica 1979, 47, 153. [CrossRef]

42. Kabeer, N. Resources, Agency, Achievements: Reflections on the Measurement of Women's Empowerment. Dev. Chang. 1999, 30, 435-464. [CrossRef]

43. Louviere, J.J.; Hensher, D.A.; Swait, J.D.; Adamowicz, W. Stated Choice Methods: Analysis and Application; Cambridge University Press: Cambridge, UK, 2000.

44. Al-Shami, S.S.; Majid, I.; Rizal, S.; Muhamad, M.R.; Halim, S.; Rashid, N. The Impact of Malaysian Microfinance on Women Livelihood. Adv. Sci. Lett. 2015, 21, 2046-2049. [CrossRef]

45. Park, H.; Cho, Y. Financial Sustainability of Nonprofit Organizations: Determinants of Fundraising Campaigns on Donation Intention. J. Ind. Distrib. Bus. 2020, 11, 19-28. [CrossRef] 